\title{
Nowo rozpoznane formy osuwiskowe w dolinie Kaczawy na Pogórzu Kaczawskim (Sudety Zachodnie)
}

\author{
Newly recognised landslide forms in the Kaczawa river valley (Kaczawskie Foothills, \\ Western Sudetes)
}

\author{
Aleksander Kowalski*, Jurand Wojewoda \\ Instytut Nauk Geologicznych, Uniwersytet Wrocławski; *aleksander.kowalski@uwr.edu.pl
}

\begin{abstract}
Zarys treści: Autorzy przedstawiają wyniki badań terenowych i analiz geomorfometrycznych nieznanych form osuwiskowych położonych w dolinie Kaczawy pomiędzy Sędziszową a Nowym Kościołem na Pogórzu Kaczawskim w Sudetach Zachodnich. Na obszarze badań rozpoznano zespół osuwisk o łącznej powierzchni ok. 21 ha na północnych stokach wzgórza Wielisławka (376,3 m n.p.m.), a także kilka mniejszych form na wschodnich stokach góry Wołek (381,7 m n.p.m.), Wygorzel (333,5 m n.p.m.) oraz osuwisk położonych w miejscowości Różana i na południowych zboczach doliny Piekiełko. Morfologia osuwisk sugeruje ich różną genezę. Rozpoznano osuwiska rotacyjne i translacyjne, jak i koluwia płytkich zsuwów i spływów gruzowo-błotnych. Rozpoznanie i wyznaczenie zasięgu form osuwiskowych w dolinie Kaczawy ma znaczenie dla dalszego poznania geologicznych i geomorfologicznych uwarunkowań rozwoju ruchów masowych w Sudetach.
\end{abstract}

Słowa kluczowe: ruchy masowe, osuwiska, LiDAR, Pogórze Kaczawskie, Sudety

Abstract: The authors present the results of field studies and geomorphometric analyzes of unknown landslide forms located in the Kaczawa river valley between Sędziszowa and Nowy Kościół (Kaczawskie Foothills, Western Sudetes). In the study area we recognised a landslide complex with a total area of about 21 ha on the northern slopes of Wielisławka hill (376.3 m a.s.l.), as well as several smaller forms on the eastern slopes of Wołek (381.7 $\mathrm{m}$ a.s.1.) and Wygorzel (333.5 $\mathrm{m}$ a.s.l.) hills and landslides located in the town of Różana and on the southern slopes of the Piekiełko valley. Morphology of recognized landslides provides evidence of different types of gravitational movements including rotational and translational landslides as well as shallow slides and earthflows. Recognition and delimitation of the landslide extent in the Kaczawa river valley is significant for further investigations of the geological and geomorphological conditioning of mass movements in the Sudetes area.

Key words: mass movements, landslides, LiDAR, Kaczawskie Foothills, Sudetes

\section{Wstęp}

O postępie badań nad ruchami masowymi w Sudetach świadczy fakt, że w ciągu ostatnich 10 lat w górskiej części Dolnego Śląska rozpoznano i opisano ponad 150 nieznanych wcześniej osuwisk różnego rodzaju (por. np. Synowiec 2003, Migoń i in. 2014, 2016, Różycka i in. 2015, Duszyński i in. 2017, Jancewicz, Traczyk 2017, Kowalski 2017 a, b). Systematyczne, geologiczne i geomorfologiczne prace kartograficzne prowadzone w dolinie Kaczawy między Sędziszową a Nowym Kościołem na Pogórzu Kaczawskim w Sudetach Zachodnich, pozwoliły na udokumentowanie kilku kolejnych, nieznanych dotąd osuwisk. W jednym $z$ udokumentowanych przypadków powierzchnia stoku objętego procesami osuwiskowymi przekracza 21 ha, co można uznać za dużą rzadkość, zwłaszcza jak na warunki sudeckie. Jakkolwiek możliwość występowania wielkoskalowych ruchów masowych w dolinie Kaczawy była postulowana wcześniej przez Traczyka (2011), to dokładny zasięg potencjalnych form osuwiskowych nie został wówczas określony. Jedynym znanym osuwiskiem $z$ obszaru badań była niewielka forma, która powstała w latach 60. XX wieku, na wschodnich stokach góry Wygorzel, na południe od miejscowości Nowy 
Kościół (Kryza, Niśkiewicz 1973). Ponadto w literaturze wzmiankowano osuwisko położone na północ od obszaru badań, w dolinie Kaczawy w okolicach Złotoryi (Migoń i in. 2015). Rozpoznano również formę osuwiskową znajdującą się na południe od analizowanego obszaru, w pobliżu miejscowości Wojcieszów (P. Migoń, inf. ustna). Pomimo, że osuwiska te zlokalizowane są w bliskiej odległości od obszaru badań, to $\mathrm{w}$ porównaniu do form przedstawionych w pracy zajmują stosunkowo niewielką powierzchnię i mają słabo urozmaiconą morfologię.

Największy rozpoznany przez autorów zespół osuwisk, wspomniany powyżej, występuje na północnych stokach wzgórza Wielisławka (376,3 m n.p.m.). Ponadto, wyróżniono kilka pojedynczych form o powierzchni powyżej 1 ha. Są to m.in. osuwiska na wschodnich stokach góry Wołek $(381,7 \mathrm{~m}$ n.p.m.), w miejscowości Różana, formy na stokach góry Wygorzel (333,5 m n.p.m.), a także na południowych zboczach doliny Piekiełko (ryc. 1). Osuwiska te występują przede wszystkim w obrębie wychodni skał wulkanicznych i osadowych dolnego permu (czerwonego spągowca), budujących południowo-wschodnią część synklinorium północnosudeckiego, a także skał metamorficznych, które współtworzą tzw. strukturę kaczawską (por. np. Cymerman 2011).

\section{Obszar badań}

Obszar badań położony jest w Sudetach Zachodnich, w dolinie rzeki Kaczawy, pomiędzy miejscowościami Nowy Kościół na północy a Sędziszowa na południu (ryc. 1A). Zgodnie $z$ podziałem fizyczno-geograficznym Kondrackiego (2002) jest to środkowa część Pogórza Kaczawskiego. Teren cechuje się urozmaiconą rzeźbą. Jej charakterystycznymi elementami są izolowane wzgórza tworzące ostańce denudacyjne (Wołek, Czeska Góra) lub rozległe masywy (Wielisławka) wznoszące się ponad faliste i pagórkowate powierzchnie zrównań położone na wysokościach od 270 do 330 m n.p.m. Zrównania są głęboko rozcięte przez doliny potoków, przyjmujące niekiedy formę dolin wciosowych o skalnych zboczach i głębokościach do ok. 35 m (np. dolina Piekiełko). Na obszarze badań występują również grzbiety o charakterze wydłużonych w kierunku NW-SE kuest ze słabo zarysowanymi wierzchołkami (Dłużyca, Krowia). Najistotniejszym elementem rzeźby jest dolina rzeki Kaczawy, która w odcinku przełomowym ma szerokość od ok. 150 do ponad $300 \mathrm{~m}$. Rzeka na tym odcinku meandruje, a dno doliny położone jest na wysokościach od ok. 245 m n.p.m. w okolicach Sędziszowej do ok. 226 m n.p.m. koło Nowego Kościoła. Różnica wysokości pomiędzy najniższymi partiami doliny a rozcinanymi wzgórzami sięga w południowej części obszaru $130 \mathrm{~m}$.
Rzeźba opisanego fragmentu doliny Kaczawy jest ściśle związana $z$ budową geologiczną podłoża (ryc. 1B) i jest w dużym stopniu uwarunkowana odpornością skał na wietrzenie i erozję. Rzeka utworzyła przełom głównie $\mathrm{w}$ masywnych skałach wulkanicznych i wulkanoklastycznych dolnego permu (czerwonego spągowca), budujących południowo-wschodnią część synklinorium północnosudeckiego (Oberc 1964). Skały wulkanogeniczne to przede wszystkim ryolity i tufy ryolitowe oraz podrzędnie trachyandezyty i trachybazalty występujące $\mathrm{w}$ formie pokryw lawowych i płytkich intruzji rozproszonych nierównomiernie na całym obszarze badań (Milewicz 1985, ryc. 1B). Intrudowały one $\mathrm{w}$ fyllity, łupki serycytowe i krzemionkowe, a także metalidyty - skały metamorficzne zaliczane do struktury kaczawskiej (metamorfiku kaczawskiego), odsłaniające się w obrębie zrębu Świerzawy (Milewicz, Kozdrój 1994), który stanowi fragment tzw. jednostki Rzeszówka-Jakuszowej (Jerzmański 1965). Zrąb Świerzawy ma bieg NW-SE i jest ograniczony prawdopodobnie wysokokątowymi uskokami normalnymi (Baranowski 1975). Znajduje się on pomiędzy dwoma jednostkami o charakterze rowów/półrowów tektonicznych w obrębie synklinorium północnosudeckiego: rowu Świerzawy na południu i półrowu Leszczyny na północy. Grubookruchowe skały osadowe górnego karbonu i dolnego permu (czerwonego spągowca) budujące te jednostki geologiczne występują w środkowej i północnej części obszaru badań (ryc. 1B).

\section{Materiały źródłowe i metodyka badań}

Badania form osuwiskowych były podzielone na dwa etapy: terenowy i kameralny. Wstępne, kartograficzne badania osuwisk $w$ dolinie Kaczawy pomiędzy Sędziszową a Nowym Kościołem przeprowadzono w latach 2016-2017. Prace kartograficzne na obszarach objętych ruchami masowymi obejmowały dokumentowanie i opis rozpoznanych $\mathrm{w}$ terenie charakterystycznych elementów rzeźby osuwiskowej, których lokalizację i pomiary powierzchni wykonano za pomocą odbiorników GPS Nomad Trimble (aplikacja ArcPad) oraz PENTAGRAM PathFinder Logger P3106. Uzupełniające pomiary odległości między takimi formami morfologicznymi jak skarpy czy nabrzmienia osuwiskowe wykonano dalmierzem laserowym Bushnell. Wszystkie naturalne i sztuczne odsłonięcia w skarpach osuwiskowych ${ }^{1}$, a także w obrębie koluwiów zostały udokumentowane pod kątem litologii tworzących je utworów, jak również

\footnotetext{
Autorzy używają terminu skarpa osuwiskowa w odniesieniu do stromego fragmentu stoku powstałego w wyniku grawitacyjnego przemieszczenia materiału, skalnego lub zwietrzelinowego (Grabowski i in. 2009).
} 

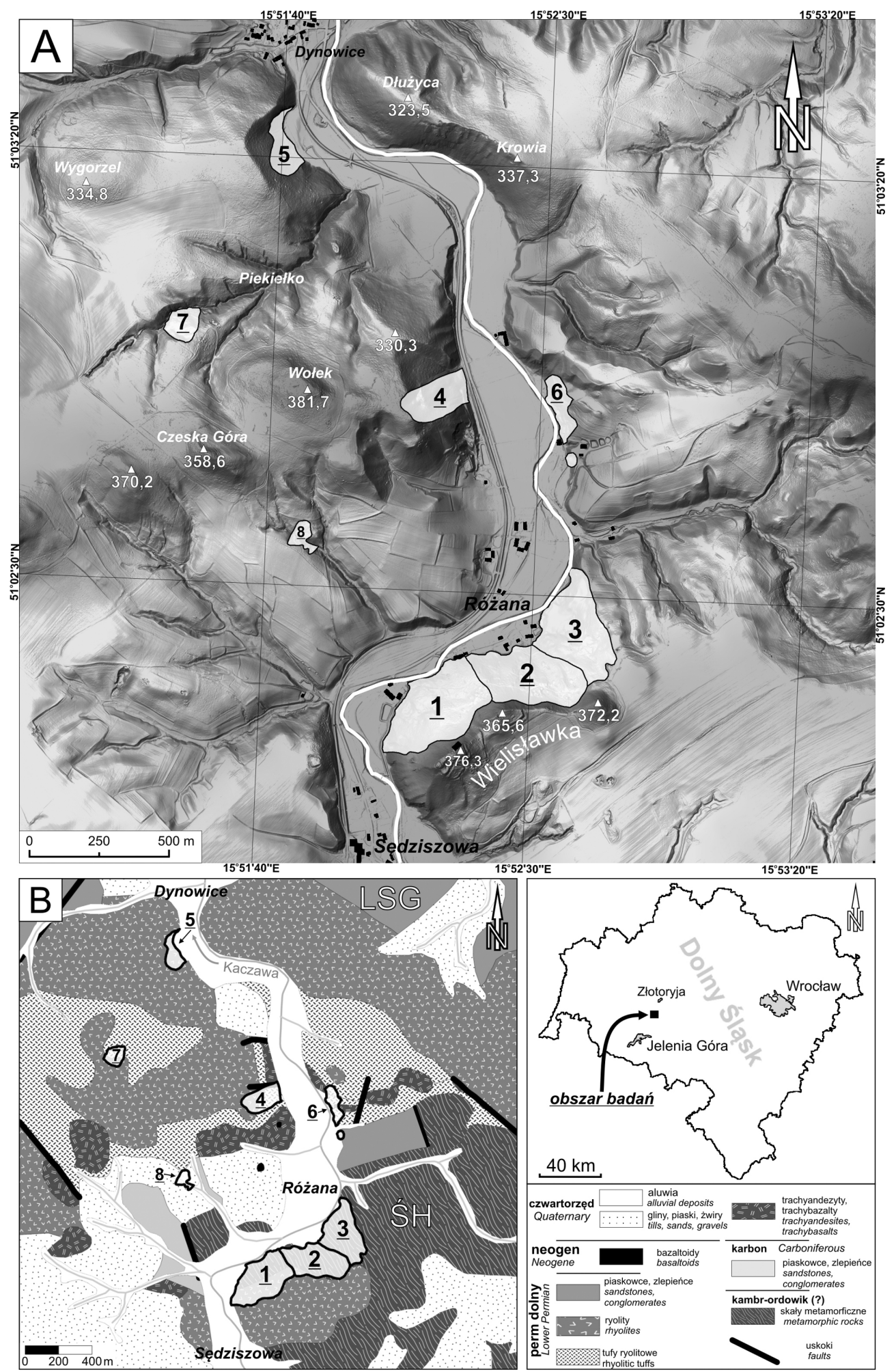

Ryc. 1. Lokalizacja obszaru badań

A - cieniowany numeryczny model terenu wygenerowany na podstawie danych wysokościowych LiDAR z naniesionymi formami osuwiskowymi: 1 - Wielisławka 1, 2 - Wielisławka 2, 3 - Wielisławka 3, 4 - Wołek, 5 - Wygorzel, 6 - Różana, 7 - Piekiełko, 8 - Czeska Góra, B - uproszczona mapa geologiczna obszaru badań (na podstawie: Zimmermann, Kühn 1929, Frąckiewicz 1958, Milewicz, Kozdrój 1995 i badań autorów), LSG - półrów Leszczyny, ŚH - zrąb Świerzawy

Fig. 1. Location map of the study area

A - LiDAR-based shaded Digital Elevation Model with superimposed landslides: 1 - Wielisławka 1, 2 - Wielisławka 2, 3 - Wielisławka 3, 4 -Wołek, 5 - Wygorzel, 6 - Różana, 7 - Piekiełko, 8 - Czeska Góra, B - simplified geological map of the study area (based on Zimmermann, Kühn 1929, Frąckiewicz 1958, Milewicz, Kozdrój 1995 and author investigations), LSG - Leszczyna Half-Graben, ŚH - Świerzawa Horst 
możliwych do bezpośredniego pomiaru elementów strukturalnych. Następnie przeprowadzono analizę geomorfometryczną form osuwiskowych wykorzystując cyfrowe modele wysokościowe LiDAR, które stanowią aktualnie najdokładniejsze, powszechnie dostępne dla analizowanego obszaru, odwzorowanie powierzchni terenu (Wężyk 2014). Dane wyjściowe wykorzystane do wykonania cieniowanych, numerycznych modeli terenu i analiz morfometrycznych pochodziły ze zbiorów (chmury) punktów uzyskanej $\mathrm{w}$ trakcie lotniczego skaningu laserowego. Skaning został wykonany na obszarze Polski w latach 2011$2014 \mathrm{w}$ ramach realizacji Informatycznego Systemu Osłony Kraju przed nadzwyczajnymi zagrożeniami (ISOK). Średnia gęstość punktów skanowania wynosiła ok. 4-6 punktów na $1 \mathrm{~m}^{2}$, a średni błąd wysokościowy przetworzonych danych nie przekracza 0,3 m (Raport dostawy ISOK... 2011).

W oparciu o cyfrowe modele wysokościowe LiDAR obliczone zostały podstawowe parametry morfometryczne rozpoznanych $\mathrm{w}$ terenie form osuwiskowych. Ponadto w celu wizualizacji zróżnicowania tych form wykonano mapy spadków i ekspozycji stoków. Standardową procedurą było również generowanie przekrojów morfologicznych prostopadłych do rozciągłości stref koluwiów osuwiskowych. Podczas prac kameralnych wykorzystano oprogramowanie MicroDEM, SAGA GIS v. 3.0.0, Global Mapper v.
15.0, a także Surfer (Golden Software) v. 9.0. Wszystkie materiały opracowano i przetwarzano $\mathrm{w}$ projekcji PUWG 1992.

\section{Charakterystyka morfologiczna form osuwiskowych}

Osuwiska zostały rozpoznane na całej długości doliny Kaczawy oraz w części dolin uformowanych przez jej dopływy pomiędzy miejscowościami Sędziszowa na południu i Nowy Kościół na północy. Udokumentowane formy osuwiskowe o największej powierzchni (tab. 1) znajdują się na północnych stokach trójwierzchołkowego masywu wzgórza Wielisławka (od zachodu: 376,3, 365,6 i 372,2 m n.p.m), wznoszącego się w południowej części obszaru badań. Deniwelacje pomiędzy wierzchołkami wzniesienia a dnem doliny Kaczawy są znaczne i sięgają maksymalnie $130 \mathrm{~m}$. Górna część wzgórza zbudowana jest z masywnych ryolitoidów wieku wczesnopermskiego, stanowiących północny fragment płytkiej intruzji o charakterze kopuły magmowej (Awdankiewicz, Szczepara 2009). W obrzeżeniu wychodni ryolitów odsłaniają się skały osłony: silnie spękane łupki serycytowe i krzemionkowe, a także metalidyty struktury kaczawskiej, zaliczane na tym obszarze do przedziału wiekowego

Tabela 1. Charakterystyka morfometryczna wybranych osuwisk w dolinie Kaczawy pomiędzy Sędziszową a Nowym Kościołem

Table 1. Morphometric characteristics of chosen landslides within the Kaczawa river valley between the Sędziszowa and Nowy Kościół towns

\begin{tabular}{|c|c|c|c|c|c|c|c|c|c|c|}
\hline $\begin{array}{l}\frac{0}{\frac{0}{n}} \\
\frac{5}{3} \\
3 \\
0 \\
0\end{array}$ & 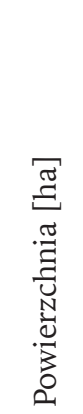 & 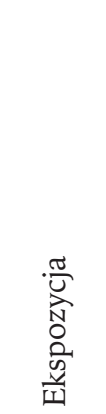 & 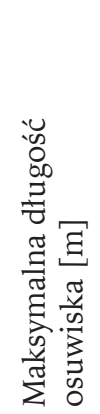 & 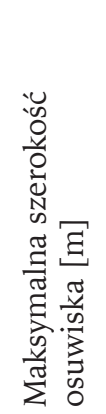 & 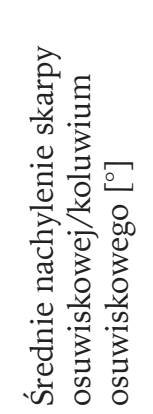 & 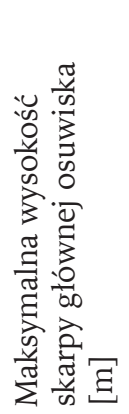 & 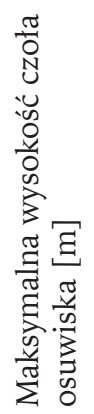 & 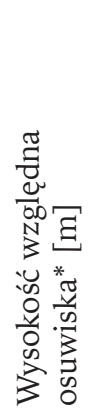 & 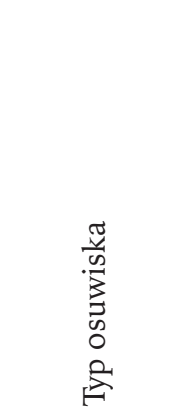 & 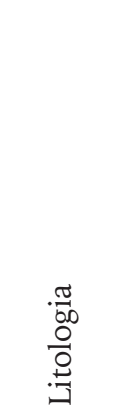 \\
\hline Wielisławka 1 & 8,06 & NW & 273,4 & 314,7 & $36,1 / 22,1$ & 34,1 & 13,0 & 104,7 & złożone & Ry, SeS \\
\hline Wielisławka 2 & 6,67 & $\mathrm{~N}$ & 308,4 & 324,1 & $33,4 / 24,9$ & 33,3 & 10,3 & 103,9 & złożone & Ry, SeS \\
\hline Wielisławka 3 & 6,73 & NW & 335,8 & 328,1 & $21,4 / 20,1$ & 29,7 & 9,8 & 98,0 & złożone & $\mathrm{SeS}$ \\
\hline Wołek & 3,17 & ENE & 256,6 & 106,6 & $34,2 / 29,4$ & 32,1 & 9,1 & 128,7 & rotacyjne & Ry, Tu \\
\hline Czeska Góra & 0,67 & $\mathrm{~S} / \mathrm{NE}$ & 110,2 & 219,3 & $28,8 / 19,2$ & 7,8 & 4,2 & 25,8 & zsuw/spływ & Q \\
\hline Wygorzel & 1,73 & $\mathrm{NE}$ & 108,3 & 151,2 & $42,8 / 33,2$ & 39,2 & 3,2 & 77,0 & translacyjne & Ry \\
\hline Piekiełko & 1,17 & NNW & 125,1 & 249,3 & $26,9 / 18,3$ & 6,4 & 3,1 & 39,9 & zsuw/spływ & Ry, Q \\
\hline Różana & 1,45 & W & 100,9 & 418,6 & $27,2 / 23,6$ & 14,5 & 7,5 & 37,5 & zsuw/spływ & Ry, Q \\
\hline
\end{tabular}

*Termin wysokość względna osuwiska zastosowany przez autorów jest tożsamy z rozpiętością pionową osuwiska (Grabowski i in. 2008), definiowaną jako różnica wysokości pomiędzy najwyżej i najniżej położonymi punktami osuwiska.

Ry - masywne ryolity, SeS - łupki serycytowe, podrzędnie łupki krzemionkowe i lidyty, Tu - tufy ryolitowe, Q - luźne utwory czwartorzędu - piaski, żwiry, podrzędnie gliny.

Ry - massive rhyolites, SeS - sericite schists, predominantly siliceous schists and lydites; Tu - rhyolitic tuffs; Q - Quaternary deposits - sands, gravels, predominantly tills. 
ordowik-karbon (Milewicz, Kozdrój 1995; por. ryc. 1B). Z brzeżnymi partiami intruzji ryolitowej związane są liczne strefy mineralizacji hydrotermalnej, w obrębie których stwierdzono występowanie minerałów kruszconośnych, m.in. pirytu, galeny, sfalerytu, arsenopirytu i chalkopirytu (Mikulski 2007). Od końca XIV w. aż do XVIII w. na stokach wzgórza prowadzono działalność górniczą w celu pozyskania tych rud (Maciejak, Maciejak 2006). Skutkowało to rozcięciem masywu licznymi szybami i sztolniami górniczymi, a także powstaniem antropogenicznych form rzeźby - szurfów, hałd i zapadlisk.

$\mathrm{Na}$ stoku przekształconym przez ruchy masowe wyznaczono trzy połączone ze sobą osuwiska o odmiennej morfologii i genezie przemieszczeń grawita- cyjnych (ryc. 1A, 2A). Największe z nich - osuwisko zachodnie (forma nr 1 na ryc. 1A) - w swojej górnej części obejmuje zespół stromych skarp o łukowatym kształcie (ryc. 3A). Skarpy, które znajdują się na wysokości 250-340 m n.p.m., uformowały się w litej skale i mają nachylenie powyżej $45^{\circ}$. Poniżej skarp rozwinęły się koluwia osuwiskowe o urozmaiconej powierzchni. W ich obrębie wyraźnie zaznaczają się nabrzmienia koluwialne, rozdzielone spłaszczeniami, które tworzą półki stokowe. W środkowej części osuwiska zachodniego, w obrębie koluwium, występuje wyraźnie zaznaczona łukowata skarpa wtórna o maksymalnej szerokości ok. 100 m i wysokości sięgającej 12 m (ryc. 2A, 3A, 3B). W skarpie odsłaniają się łupki sercytowe i fyllity. Poniżej skarpy znajduje

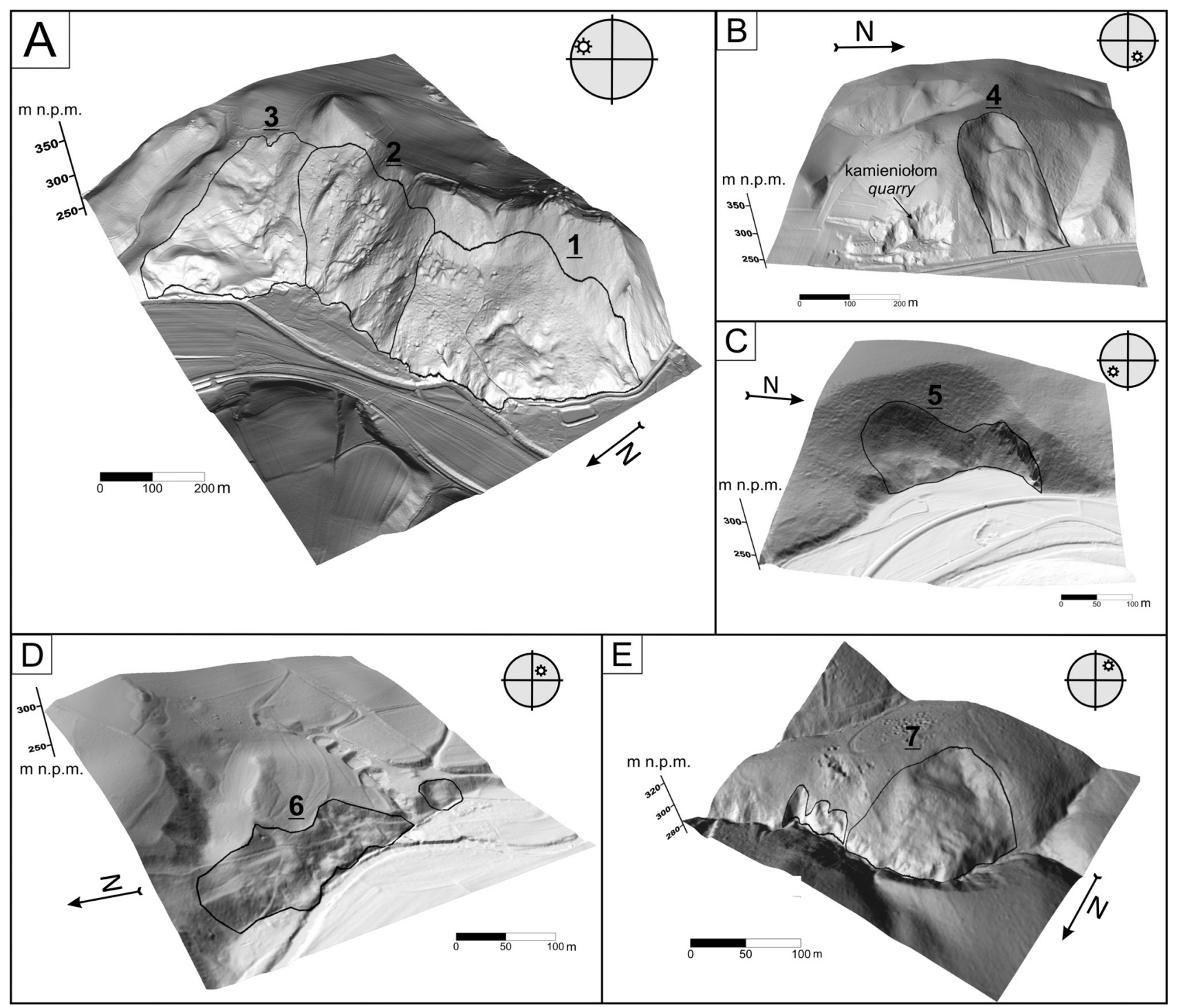

Ryc. 2. Trójwymiarowe modele rozpoznanych osuwisk wygenerowane na podstawie NMT LiDAR

Zasięg osuwisk zaznaczono czarną linią; A - Wielisławka (osuwiska nr 1, 2, 3), B - Wołek (4), C - Wygorzel (5), D - Różana (6), E Piekiełko (7)

Fig. 2. Three-dimensional terrain models of the investigated landslides generated from the LiDAR DEM

Extent of landslides marked by black lines; A - Wielisławka (landslides no. 1, 2, 3), B - Wołek (4), C - Wygorzel (5), D - Różana (6), E - Piekiełko (7) 
się wstecznie pochylona półka skalna ograniczona od strony zewnętrznej niewysokim (do ok. 1,5 m) wałem osuwiskowym. Co ciekawe, w obrębie form o genezie osuwiskowej, poniżej skarpy wtórnej występują niewielkie zapadliska i mała hałda. Formy te pochodzą najprawdopodobniej z najstarszego okresu eksploatacji górniczej prowadzonej na tym obszarze (por. Maciejak i in. 2017), datowanego na XIV w. Na wschód od skarpy wtórnej, w obrębie koluwium osuwiska nr 1 znajdują się złaziska i małe nabrzmienia koluwialne. Ta część wzgórza jest najbardziej przekształcona przez działalność górniczą - występują

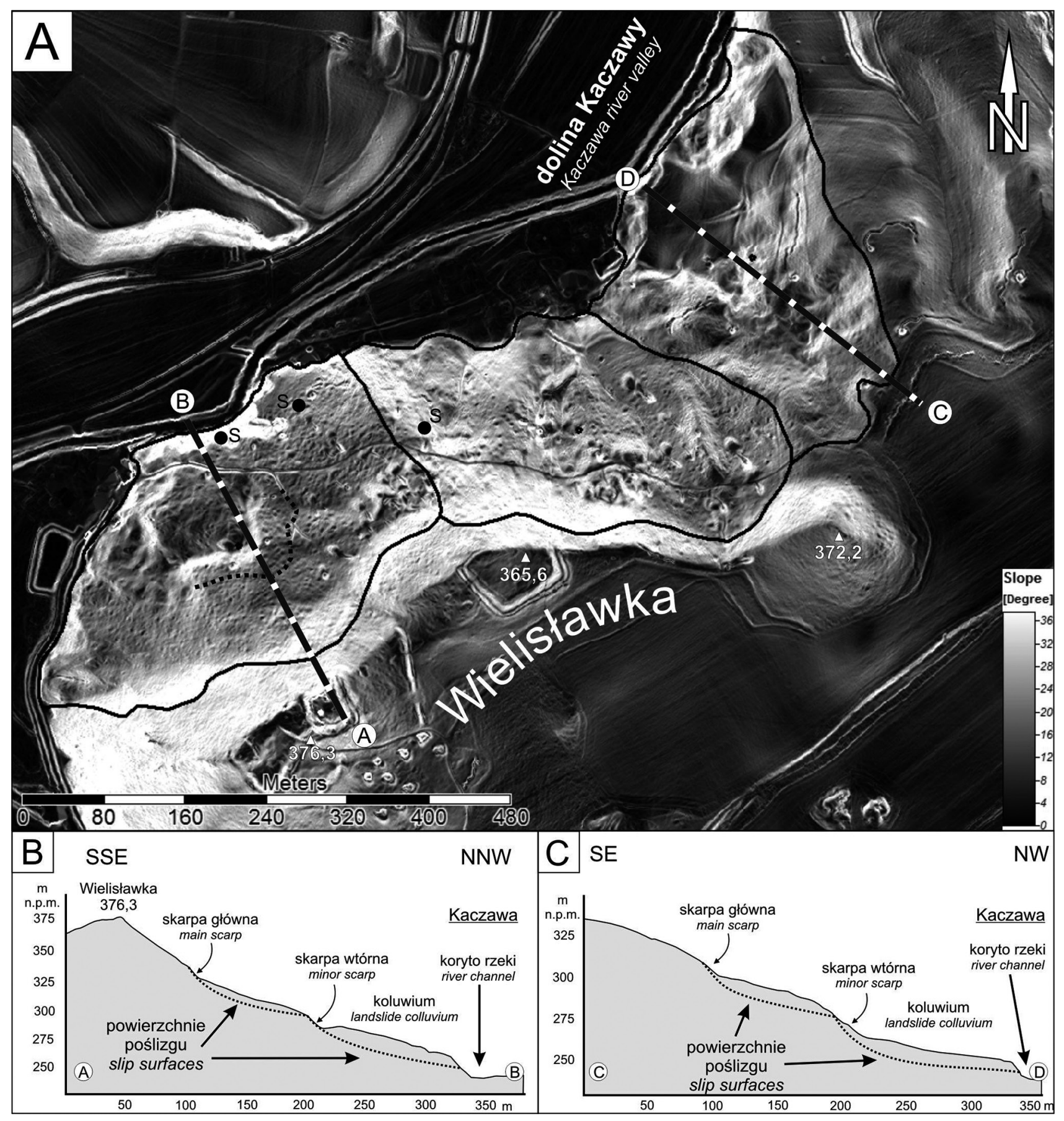

Ryc. 3. Numeryczny model terenu przedstawiający nachylenie stoków (A) okolic wzgórza Wielisławka wygenerowany na podstawie cyfrowego modelu wysokościowego LiDAR

Zasięg osuwisk zaznaczono czarną linią; przekroje morfologiczne A-B i C-D przedstawiono na rycinach B i C; literą „S” oznaczono drożne wyloty sztolni opisane w tekście

Fig. 3. Slope angle map (A) of Wielisławka Hill generated from the LiDAR DEM

Extent of landslides are marked by black lines; morphological cross-sections (A-B and C-D) from the figures 3B and 3C are indicated; shafts and old adits described in the text are marked („S”) 
tu wyloty kilkunastu krótkich sztolni (obecnie zasypane) i niewielkie hałdy. W dolnej części osuwiska, na wysokościach ok. 250 i 254 m n.p.m., powyżej dna doliny Kaczawy znajdują się dwa drożne wyloty sztolni. Jedna $z$ nich - sztolnia zachodnia - opisana przez Zöllera (1936), została wydrążona najprawdopodobniej wzdłuż wcześniej powstałej szczeliny osuwiskowej (Kowalski 2017c), znanej w literaturze i w przewodnikach turystycznych jako tzw. Jaskinia Wielisławska (np. Cedro i in. 2009). Powyższy pogląd może potwierdzać lokalizacja sztolni, bowiem znajduje się ona na przedłużeniu skarpy wtórnej osuwiska nr 1. Czoło osuwiska, które schodziło prawodopodobnie do koryta rzeki Kaczawy, zostało również przekształcone w wyniku działalności górniczej.

$\mathrm{Na}$ wschód od opisanej formy znajduje się osuwisko $\mathrm{nr} 2$ (ryc. 1A, 2A, 3A), które ograniczone jest od osuwiska nr 1 wydłużonym grzbietem o orientacji NNW-SSE, wzdłuż którego wyznaczono granicę osuwiska nr 1 i 2 . Osuwisko nr 2 ma najmniej urozmaiconą rzeźbę spośród rozpoznanych form. Poza słabo zaznaczonym ciągiem skarp o nachyleniu do ok. $38^{\circ}$, w środkowej partii stoku występują formy o charakterze płytkich zsuwów zwietrzelinowych, w obrębie których stwierdzono złaziska i nabrzmienia koluwialne. $\mathrm{W}$ obrębie koluwium stwierdzono ponadto występowanie bloków skalnych o średnicy nawet do $5 \mathrm{~m}$. Czoło osuwisk ma formę niskich jęzorów osuwiskowych, które uległy częściowemu zatarciu w wyniku zabudowania terenu w miejscowości Różana.

Do osuwiska nr 2 przylega od północnego wschodu osuwisko nr 3 (ryc. 1A, 2A, 3A), które charakteryzuje się najbardziej urozmaiconą rzeźbą spośród form rozpoznanych na stokach Wielisławki. Osuwisko to wystąpiło na stoku zbudowanym na całej swej długości ze skał metamorficznych - łupków serycytowych i krzemionkowych zaliczanych do struktury kaczawskiej (por. ryc. 1A). W jego górnej części znajdują się dwie łukowate skarpy o łącznej szerokości $150 \mathrm{~m}$ (por. ryc. 3A, 3C). Poniżej skarp występuje wstecznie pochylony w kierunku południowym pakiet skalny, na powierzchni którego utworzyło się bezodpływowe zagłębienie, okresowo wypełnione wodą. Ponadto na powierzchni koluwium osuwiskowego znajdują się liczne skarpy, progi i nabrzmienia. W dolnej części osuwiska dominują złaziska o łukowatych zarysach. Koluwium osuwiskowe zakończone jest wyraźnym czołem schodzącym do dna doliny rzeki Kaczawy (ryc. 3A, 3C).

Cechy morfologiczne osuwisk występujących na stokach Wielisławki pozwalają na wnioskowanie o ich złożonej genezie. Wstecznie pochylone pakiety skalne przylegające do stromych, łukowatych w zarysie skarp, występujących w obrębie osuwisk nr 1 i 3 wskazują na rotacyjny charakter ruchu mas skalnych i względnie głębokie (>20 m) założenia powierzchni poślizgu. Penetratywne spękania ekstensyjne o dużym rozwarciu, zaobserwowane w chodnikach sztolni zachodniej (Kowalski 2017c) potwierdzają tezę o głębokich założeniach tych form. Niewykluczone, że w dystalnych częściach osuwisk dominowały przemieszczenia typu spływowego, o czym świadczą partie stoku o pagórkowatej rzeźbie, a także niewysokie jęzory osuwiskowe zbudowane głównie $z$ wielofrakcyjnego materiału skalnego. Formy rzeźby wskazujące na występowanie płytkich zsuwów zwietrzelinowych i spływów błotno-gruzowych (niewysokie nabrzmienia koluwialne, niskie skarpy przechodzące we fragmenty stoku o falistej i pagórkowatej rzeźbie, złaziska) przeważają na obszarze osuwiska nr 2 i we wschodniej części osuwiska nr 1 (por. ryc. 3).

$\mathrm{Na}$ wschodnich stokach góry Wołek 381,7 m n.p.m. występuje kolejne rozpoznane osuwisko o powierzchni 3,17 ha (nr 4 na ryc. 1A, 2B). Forma ta rozwinęła się $\mathrm{w}$ obrębie masywnych ryolitów i niżej leżących tufów ryolitowych (por. ryc. 1B). Osuwisko wykształciło wyraźną rynnę o szerokości do ok. 105 m i długości do $256 \mathrm{~m}$, której górną część stanowi bardzo dobrze zachowana, stroma skarpa główna wykształcona w litej skale podłoża. Poniżej skarpy głównej osuwiska występuje wstecznie zrotowany pakiet osuwiskowy obcięty skarpą wtórną (ryc. 4A, 4B), w obrębie której odsłaniają się masywne ryolity i ich tufy. Poniżej, na całej powierzchni stoku objętej procesem osuwania, w obrębie koluwium występują ryolitowe rumowiska skalne, a także nabrzmienia i niewielkie skarpy. Osuwisko zakończone jest wysokim czołem, które w części południowej zostało zniwelowane i przykryte hałdą nieczynnego obecnie kamieniołomu trachybazaltu położonego ok. $100 \mathrm{~m}$ na południe. Forma na wschodnich stokach Wołka wykazuje cechy głębokiego skalnego osuwiska rotacyjnego. Wskazuje na to wyraźnie pochylony i zrotowany skalny pakiet osuwiskowy stwierdzony poniżej skarpy głównej osuwiska (ryc.4A).

$\mathrm{Na}$ wschodnich stokach wzniesienia Wygorzel (333,5 m n.p.m.) występuje osuwisko (nr 5 na ryc. 1A), które powstało na skutek nawalnych opadów deszczu w 1967 r. (Kryza, Niśkiewicz 1973, Florek, Olszowa 2008). Na stromym zachodnim zboczu doliny Kaczawy utworzyły się dwie skarpy o łukowatym przebiegu, poniżej których występują koluwia o słabo urozmaiconej rzeźbie (ryc. 1A, 2C). W północnej części osuwiska skarpa uformowała się w skałach podłoża. Na powierzchni koluwiów występują niewysokie nabrzmienia i niewysokie (do $1 \mathrm{~m}$ ) skarpy. Niemal wszystkie formy terenu w obrębie osuwiska przykryte są pokrywami blokowymi, składającymi się z ostrokrawędzistych fragmentów ryolitów. W części południowej osuwiska, w obrębie koluwiów znajdują się niewielkie, podziemne wyrobiska wydrążone przez poszukiwaczy agatów. Czoło osuwisk jest słabo zaznaczone. Osuwiska na górze Wygorzel po- 

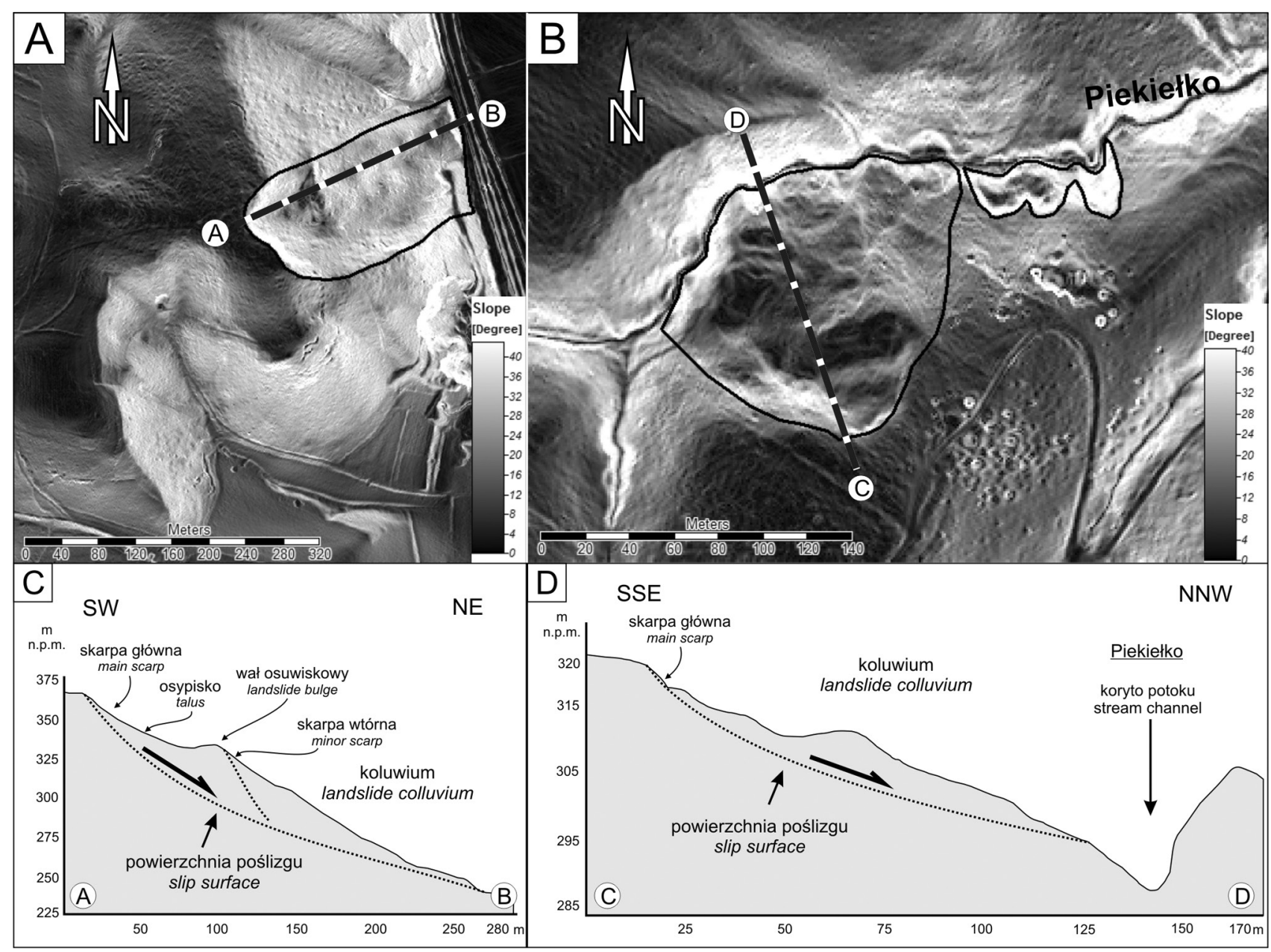

Ryc. 4. Numeryczne modele terenu przedstawiające nachylenie stoków okolic wzgórza Wołek (A) i górnej części doliny Piekiełko (B) wygenerowane na podstawie cyfrowego modelu wysokościowego LiDAR

Zasięg osuwisk zaznaczono czarną linią; przekroje morfologiczne A-B i C-D przedstawiono na rycinach C i D

Fig. 4. A. Slope angle maps of the Wołek Hill (A) and the upper part of the Piekiełko valley (B) generated from the LiDAR DEM

Extent of landslides are marked by black lines; morphological cross-sections (A-B and C-D) from the figures 4C and 4D are indicated

wstały najprawdopodobniej w wyniku translacyjnych przemieszczeń mas skalnych, jednak ze względu na brak odsłonięć w górnej części skarpy głównej osuwiska oraz pokrywy blokowe o znacznej miąższości, przykrywające powierzchnię poślizgu mas skalnych, hipoteza ta wymaga dalszej weryfikacji.

Na obszarze badań rozpoznano również kilka niewielkich form osuwiskowych o powierzchni poniżej 2 ha (ryc. 1, Tab. 1). Występują one na zboczach doliny Kaczawy, a także w obrębie głęboko wciętych, krótkich dolin potoków stanowiących jej lewobrzeżne dopływy. Największa z tych form (nr 6 na ryc. 1A) objęła swym zasięgiem wschodnie zbocza doliny w miejscowości Różana (ryc. 1A, 2D). Mniejsze z rozpoznanych osuwisk znajdują się w dolinie nazywanej Piekiełkiem (forma nr 7 na ryc. 1A, 2E), a także w dolinie bezimiennego potoku na południowych stokach wzgórza Wołek (forma nr 8 na ryc. 1A). Osuwiska rozwinęły się w obrębie pokryw zwietrzelinowych wykształconych na ryolitach i ich tufach (formy nr 6, 7), a także w obrębie luźnych, żwirowo-piaszczystych osadów czwartorzędu (forma nr 8). Wszystkie z wymienionych osuwisk charakteryzują się słabo zarysowanymi skarpami głównymi i rozległą strefą depozycji materiału koluwialnego poniżej (ryc. 4C, 4D). Koluwia osuwiskowe mają urozmaiconą, falisto-pagórkowatą rzeźbę i kończą się niewysokim czołem. Osuwiska te powstały w wyniku płytkich zsuwów, a także spływów gruzowo-błotnych w obrębie silnie zawodnionych pokryw zwietrzelinowych utworzonych najczęściej powyżej wychodni tufów ryolitowych.

\section{Dyskusja}

Dzięki pracom terenowym i analizom cyfrowych modeli wysokościowych LiDAR było możliwe wyznaczenie stref i zespołów form terenu charakterystycznych dla stoków objętych wielkoskalowymi ruchami ma- 
sowymi. W górnej części stoków i zboczy dolin były to przede wszystkim wyraźne zestromienia w postaci łukowatych lub prostolinijnych $\mathrm{w}$ zarysie skarp stanowiących odsłonięte, górne fragmenty powierzchni odkłucia i poślizgu mas skalnych i zwietrzelinowych. W przypadku osuwisk rotacyjnych rozwiniętych czę-
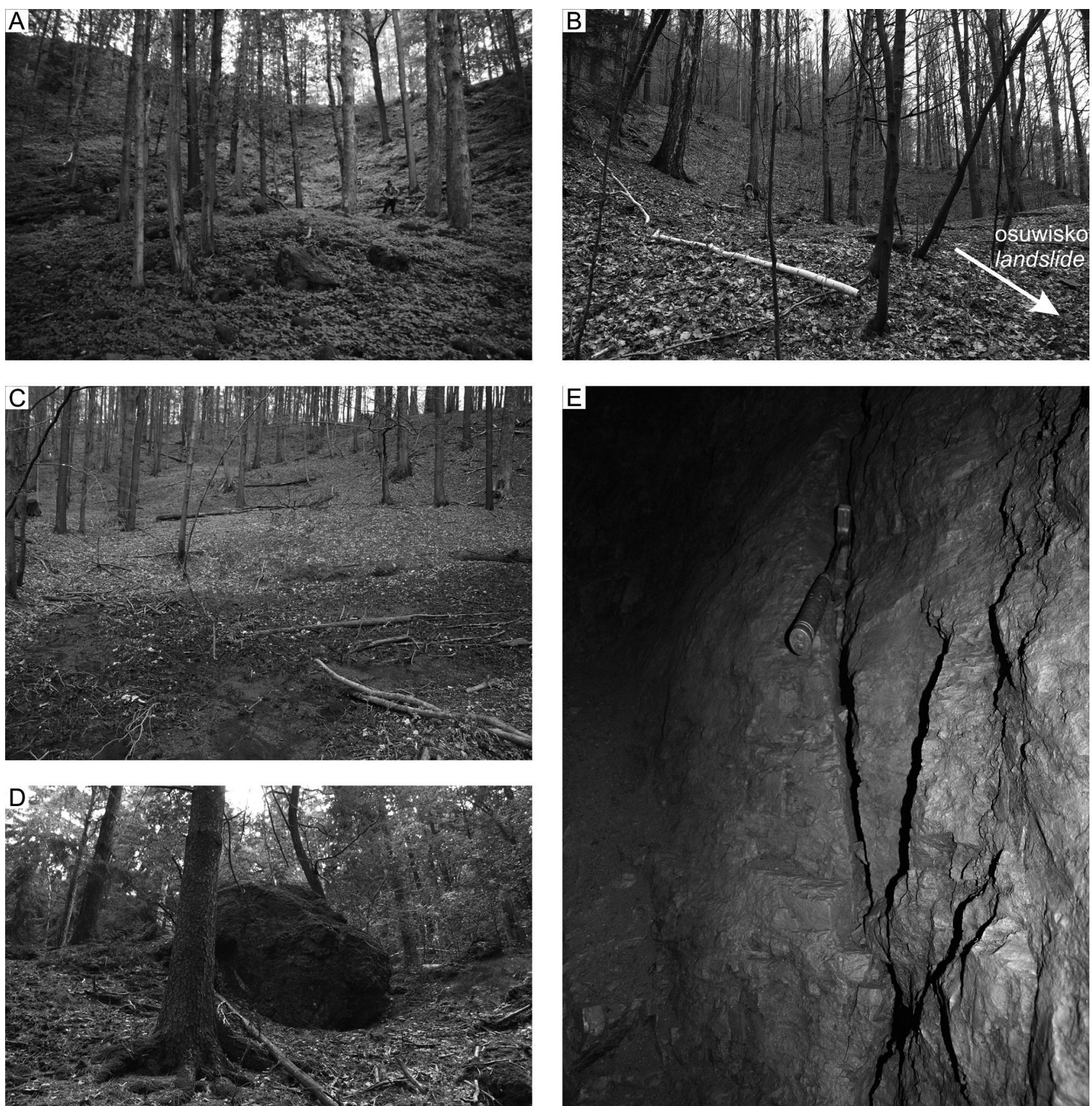

Ryc. 5. Cechy rzeźby wybranych osuwisk w dolinie Kaczawy

A - skalista, ryolitowa skarpa o półkolistym zarysie (osuwisko nr 4), B - wstecznie pochylona półka skalna poniżej skarpy wtórnej osuwiska nr 1, C - koluwium osuwiska nr 3 z widoczną falistą i pagórkowatą rzeźbą. Poniżej zagłębienie bezodpływowe wypełniane okresowo woda, D - izolowany, przemieszczony blok lidytu o średnicy $4 \mathrm{~m} \mathrm{w}$ obrębie osuwiska nr 2, E - szczelina osuwiskowa poniżej skarpy osuwiska nr 1 odsłonięta w sztolni zachodniej opisanej przez Zöllera (1936)

Fig. 5. Morphology of the chosen landslides in the Kaczawa river valley

A - rocky, rhyolitic arcuate steep scarp (landslide no. 4), B - backward tilted rocky block below the minor scarp of the landslide no. 1, C - wavy and hummocky relief of the landslide no. 3 colluvium and closed depression filled with water below, D - isolated, displaced block of lydite with a diameter of ca. $4 \mathrm{~m}$ within landslide no. 2 colluvium, E - landslide tension crack below the secondary scarp of the landslide no. 1 crop out in the western adit described by Zöller (1936) 
moszem skalnym. W obrębie osuwisk rozwiniętych w skałach metamorficznych (nr 3) lub płytkich zsuwów obejmujących pokrywy zwietrzelinowe i luźne utwory czwartorzędowe (formy $\mathrm{nr} 6,7,8$ ) główna skarpa osuwiskowa jest niska, słabiej zarysowana, a w jej obrębie nie odsłaniają się skały podłoża.

W każdej z analizowanych form, elementy rzeźby osuwiskowej występujące w środkowej części stoku obejmowały m.in. półki skalne, bezodpływowe zagłębienia, mniejsze skarpy, a także nabrzmienia koluwialne przechodzące najczęściej w wyraźny w próg akumulacyjny (czoło osuwiska). Pozwoliły one odróżnić w sposób jednoznaczny fragmenty stoków osuwiskowych od przyległych powierzchni stokowych nieobjętych procesem osuwania. Niektóre $z$ tych form dały podstawę do wnioskowania o charakterze przemieszczeń w obrębie osuwisk. Schodowy układ powierzchni stokowych będący efektem osunięcia zwartych pakietów skalnych, a także wstecznie pochylone półki osuwiskowe (ryc. 5B), obcięte często skarpami wtórnymi (osuwiska nr 1, 3, 4) świadczą o ich rotacyjnym charakterze, a co za tym idzie o większym zasięgu głębokościowym powierzchni poślizgu osuwiska. Pakiety głębokich rotacyjnych osuwisk skalnych stopniowo $\mathrm{w}$ dół stoku ulegają dezintegracji i zmieniają swój charakter na osuwiska spływowe, spływy rumoszowo-błotne, a nawet w lawiny kamienne. Świadczą o tym rozległe obszary o pagórkowatej i falistej rzeźbie (ryc. 5C) znajdujące się poniżej osuniętych i zrotowanych pakietów skalnych (osuwisko nr 3), duże bloki skalne przetransportowane w dół stoku na dużą odległość od wychodni skał podłoża w skarpie głównej (osuwisko nr 2, ryc. 5D), a także rozległe pokrywy głazowo-blokowe (osuwisko nr 4) i złaziska. Płytkie formy osuwiskowe, będące efektem spływów błotno-gruzowych i płytkich ześlizgów zwietrzelinowych cechują się urozmaiconą rzeźbą w części środkowej i niskimi strefami czołowymi.

Na szczególną uwagę zasługują antropogeniczne formy rzeźby występujące $\mathrm{w}$ obrębie rozpoznanych
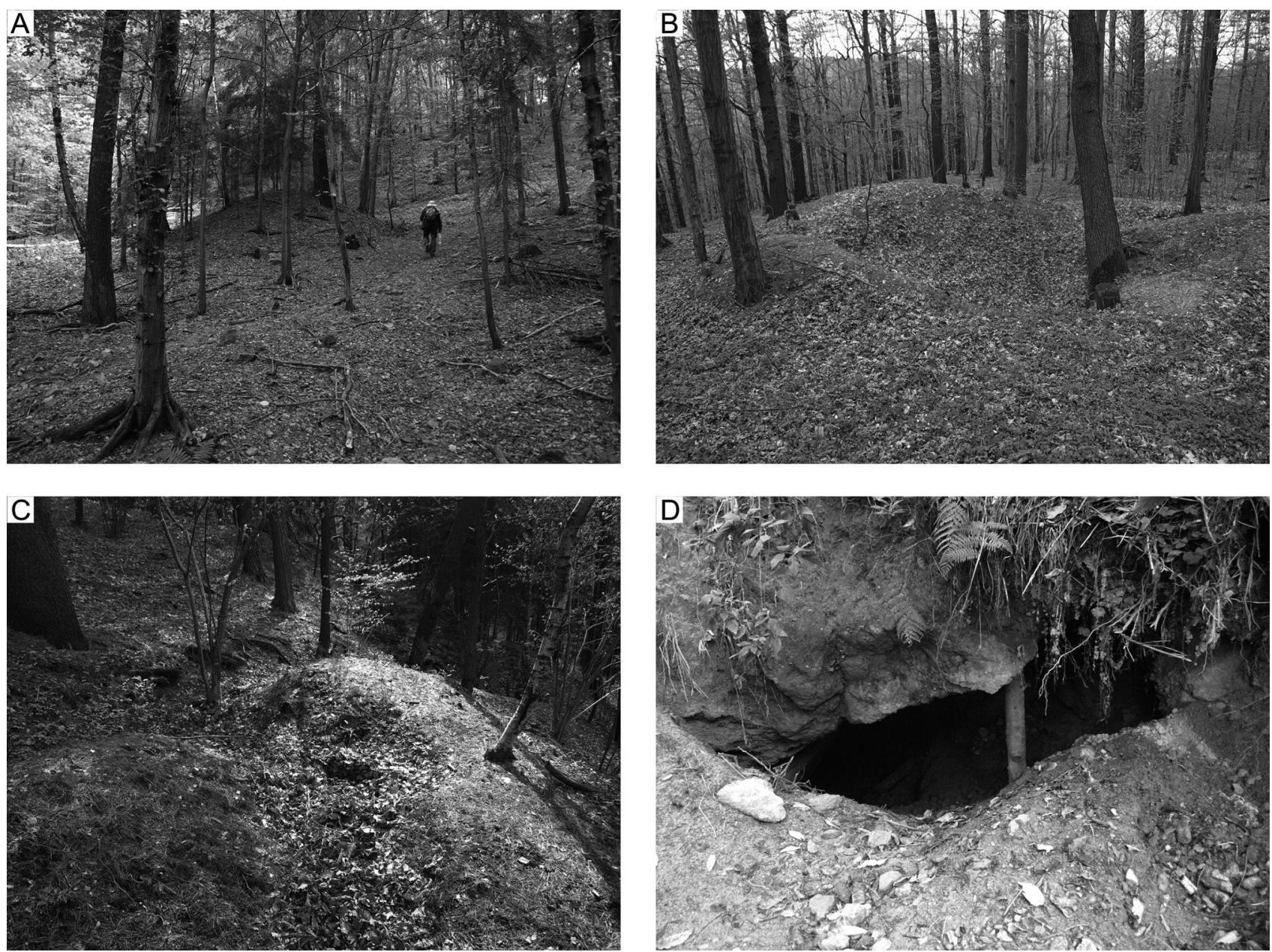

Ryc. 6. Antropogeniczne formy rzeźby w obrębie osuwisk doliny Kaczawy

A - niewielka hałda w obrębie osuwiska nr 2, B - zapadlisko powyżej skarpy głównej osuwiska nr 3, C - okop pochodzący z czasów II wojny światowej w obrębie formy osuwiskowej nr 3, D - sztolnia wydrążona przez poszukiwaczy minerałów w obrębie osuwiska nr 5

Fig. 6. Anthropogenic forms within the landslides in the Kaczawa river valley

A - small dump in the landslide no. 2 area, B - small sinkhole above the main scarp of the landslide no. 3, C - Trench from the Second World War within the landslide no. 3, D - adit excavated by mineral prospectors within the landslide no. 5 
form osuwiskowych (ryc. 6). Ich rozróżnienie miało kluczowe znaczenie dla interpretacji i wyznaczenia zasięgu ruchów masowych na obszarze badań. W przypadku osuwisk występujących na stokach Wielisławki (nr 1, 2 i 3) są to ślady historycznej działalności górniczej, ale również pozostałości działań wojennych z XX w. Kwerenda materiałów archiwalnych (Maciejak i in. 2017) wykazała, że eksploatacja minerałów kruszcowych nie była prowadzona tu na dużą skalę, a ślady górnictwa - choć liczne - ograniczają się do pojedynczych, niewielkich form lub ich skupisk (wąskie wyloty sztolni, małe hałdy, zawalone wąskie szyby). Niektóre $z$ podziemnych wyrobisk znajdują się $\mathrm{w}$ obrębie koluwiów głębokich osuwisk rotacyjnych (osuwisko $\mathrm{nr}$ 1), co potwierdzają obserwacje przeprowadzone $\mathrm{w}$ chodnikach sztolni, w których stwierdzono liczne szczeliny o rozwarciu do kilkunastu $\mathrm{cm}$ (por. ryc. 5E). Paradoksalnie, szczeliny te nie występują w płytkich, początkowych odcinkach sztolni zachodniej opisanej przez Zöllera (1936), a stwierdzono je w najgłębszych partiach wyrobisk. Jest to spowodowane faktem, że końcowe partie sztolni znajdują się bezpośrednio poniżej skarpy wtórnej osuwiska nr 1, a wyrobiska były drążone na jej przedłużeniu $z$ wykorzystaniem pustek podziemnych typu jaskiń szczelinowych (Kowalski 2017 b, Maciejak i in. 2017), określanych wcześniej błędnie w literaturze jako naturalne szczeliny wulkaniczne (Stefaniuk, Ilcewicz-Stefaniuk 2012) lub, co bardziej kuriozalne, jako szczeliny wentylacyjne wulkanu (Cedro $\mathrm{i}$ in. 2009). Pomimo pozornego podobieństwa form antropogenicznych do elementów rzeźby powstałych w wyniku ruchów masowych (por. ryc. 6) lub form powstałych w efekcie innych procesów rzeźbotwórczych (Ozimkowski i in. 2010), skala występowania form osuwiskowych na stokach Wielisławki jest nieporównywalnie większa. Potwierdziły to badania terenowe i analizy cyfrowych modeli wysokościowych LiDAR, które umożliwiły precyzyjne rozdzielenie form rzeźby antropogenicznej i osuwiskowej. Ponadto, niektóre $z$ form osuwiskowych, zwłaszcza skarpy główne osuwisk nr 1, 2 i 3 znajdują się poza obszarami, na których prowadzono eksploatację (Maciejak i in. 2017), co wyklucza możliwość ich antropogenicznego pochodzenia.

Powstanie form antropogenicznych na obszarze osuwiska na stokach góry Wygorzel (forma nr 5) było bezpośrednim efektem procesów osuwiskowych. Wystąpienie dużego osuwiska na zboczu doliny Kaczawy w 1967 r. odsłoniło nowe wychodnie ryolitów i tufów ryolitowych znanych $z$ wystąpień agatów (Kryza, Niśkiewicz 1973). Doprowadziło to do powstania i dalszej eksploatacji nielegalnych, głębokich wyrobisk i sztolni wydrążonych tu przez poszukiwaczy minerałów. Ze względu na lokalizację tych form poniżej skarpy głównej osuwiska nr 5, a także możliwość wtórnych przemieszczeń pojedynczych bloków skalnych w obrębie koluwium, formy te stwarzają realne zagrożenie dla życia i zdrowia poszukiwaczy kamieni szlachetnych i leśników.

\section{Podsumowanie}

Szczegółowe terenowe prace kartograficzne, a także analizy geomorfometryczne wysokorozdzielczych, cyfrowych modeli wysokościowych LiDAR umożliwiły precyzyjne wyznaczenie zasięgu, rozprzestrzenienia, a także szeregu parametrów charakteryzujących formy osuwiskowe występujące $w$ przełomowej dolinie Kaczawy pomiędzy Sędziszową a Nowym Kościołem na Pogórzu Kaczawskim. Dane lidarowe, które stały się w ostatnich kilku latach powszechnie dostępne dla obszaru Polski, przyczyniły się do rozpoznania licznych, nieznanych wcześniej osuwisk w Sudetach (Migoń i in. 2014, 2015, 2016, Sikora i in. 2017, Kowalski 2017 a, b) i Karpatach (Długosz 2012, Graniczny i in. 2012, Łajczak i in. 2014). Ponadto modele te stanowią obecnie ważne wsparcie dla geologicznych prac kartograficznych (np. Wojewoda $\mathrm{i}$ in. 2011, Wojewoda 2016, Kowalski 2017d).

Morfologia rozpoznanych osuwisk sugeruje ich różną genezę. Rozpoznano zarówno typowe grawitacyjne osuwiska rotacyjne i translacyjne, jak i koluwia masowych spływów grawitacyjnych. Niektóre z osuwisk wykazują złożoną strukturę, co wskazuje na udział wielu procesów w ich powstaniu. Na szczególną uwagę zasługują ruchy masowe obejmujące północne stoki góry Wielisławka, gdzie od XIV do XVIII w. była prowadzona podziemna działalność górnicza utworów srebro- i złotonośnych (Maciejak, Maciejak 2006). Badania terenowe wykazały, że liczne formy pogórnicze (zapadliska, zasypane wyloty sztolni, niewielkie hałdy) znajdują się w obrębie koluwiów osuwiskowych. Co więcej, niektóre ze sztolni drążono, wykorzystując najprawdopodobniej szczelinowe jaskinie powstałe wcześniej w obrębie osuwisk (m.in. tzw. Jaskinia Wielisławska; por. Maciejak i in. 2017). $\mathrm{Na}$ stokach Wielisławki potwierdzono także występowanie okopów i umocnień ziemnych z czasów II wojny światowej. Rozróżnienie wymienionych wyżej elementów rzeźby było kluczowe dla wyznaczenia zasięgu osuwisk $\mathrm{w}$ tym regionie i było możliwe zarówno podczas prac terenowych, jak i poprzez analizę geomorfometryczną terenu w oparciu o cyfrowe modele wysokościowe LiDAR.

Rozpoznanie i wyznaczenie zasięgu osuwisk w dolinie Kaczawy ma znaczenie dla dalszego poznania geologicznych i geomorfologicznych uwarunkowań rozwoju procesów osuwiskowych w Sudetach i stanowi uzupełnienie obecnego stanu wiedzy na temat ruchów masowych na tym obszarze. W niniejszej pracy po raz kolejny wykazano przydatność 
analiz opartych na cyfrowych modelach wysokościowych LiDAR, które obok tradycyjnych prac terenowych, stanowią przydatne narzędzie $\mathrm{w}$ rozpoznaniu form rzeźby, zwłaszcza tych ukrytych pod zwartą pokrywą roślinną.

\section{Podziękowania}

Autorzy są wdzięczni dwóm anonimowym Recenzentom za wnikliwe i cenne uwagi, które przyczyniły się do znacznego ulepszenia i urozmaicenia pierwszej wersji pracy. Dziękujemy Krzysztofowi Maciejakowi za pomoc w badaniach terenowych. Badania sfinansowano ze środków przeznaczonych na rozwój młodych naukowców (nr projektu 0420/2285/17) Wydziału Nauk o Ziemi i Kształtowania Środowiska Uniwersytetu Wrocławskiego.

Dane LiDAR zostały wykorzystane przez autorów na podstawie licencji DIO.DFT.DSI.7211.1619.2015 PL_N wydanej przez Głównego Geodetę Kraju dla Wydziału Nauk o Ziemi i Kształtowania Środowiska Uniwersytetu Wrocławskiego.

\section{Literatura}

Awdankiewicz M., Szczepara N., 2009. Structure, textures, petrography and mineral chemistry of the Wielisławka rhyolites (Permian), the North-Sudetic Basin. Mineralogia - Special Papers 34: 10.

Baranowski Z., 1975. Zmetamorfizowane osady fliszowe północnej części Gór Kaczawskich (jednostka Rzeszowek-Jakuszowa). Geologia Sudetica 10: 119-151.

Cedro B., Mianowicz K., Zawadzki D., 2009. Ocena walorów geoturystycznych stanowisk pochodzenia wulkanicznego Gór i Pogórza Kaczawskiego. W: Dudkowski M. (red.), Problemy turystyki i rekreacji 2: 25-35.

Cymerman Z., 2004. Tectonic map of the Sudetes and the Fore-Sudetic Block (1:200 000). Państwowy Instytut Geologiczny, Warszawa.

Długosz M., 2012. Digital terrain model (DTM) as a tool for landslide investigation in the Polish Carpathians. Studia Geomorphologica Carpatho-Balcanica 46: 5-23.

Duszyński F., Jancewicz K., Kasprzak M., Migoń P., 2017. The role of landslides in downslope transport of caprock-derived boulders in sedimentary tablelands, Stołowe Mts, SW Poland. Geomorphology 295: 84-101.

Florek W., Olszowa A., 2008. Morfologiczne skutki eksploatacji agatów w dolinie środkowej Kaczawy. Landform Analysis 9: 280-284.

Frąckiewicz W., 1958. Szczegółowa Mapa Geologiczna Sudetów 1:25 000. Arkusz Świerzawa. Wydawnictwa Geologiczne, Warszawa.

Graniczny M., Kamiński M., Piątkowska A., Surała M., 2012. Wykorzystanie lotniczego skaningu laserowego do inwentaryzacji i monitoringu osuwiska w rejonie Łaśnicy (gmina Lanckorona), Pogórze Wielickie, Karpaty zewnętrzne. Przegląd Geologiczny 60(2): 89-94.

Jancewicz K., Traczyk A., 2017. Mało znane formy ruchów masowych w dolinie Węglówki w Górach Bardzkich (Sudety Środkowe). Przyroda Sudetów 20: 289-314.

Jerzmański J., 1965. Budowa geologiczna północno-wschodniej części Gór Kaczawskich i ich wschodniego przedłużenia. Biuletyn Instytutu Geologicznego 185: 109-193.
Kondracki J., 2002. Geografia regionalna Polski. PWN, Warszawa.

Kowalski A., 2017a. Ruchy masowe a interpretacja budowy geologicznej - przykład osuwiska na górze Drogosz w paśmie Zaworów (Sudety Środkowe). Przegląd Geologiczny 65(2): 96-104.

Kowalski, A., 2017b. Rozmieszczenie i geneza form osuwiskowych $\mathrm{w}$ przełomowej dolinie Bobru w okolicach Wlenia (Sudety Zachodnie). Przegląd Geologiczny 65(10/1): 629-641.

Kowalski, A., 2017c. Nieznane formy osuwiskowe w przełomowej dolinie Kaczawy między Sędziszową a Nowym Kościołem (Pogórze Kaczawskie, Sudety Zachodnie). XI Zjazd Geomorfologów Polskich, Naturalne i antropogeniczne uwarunkowania rozwoju rzeźby, 13-15.09.2017 r., Warszawa. Streszczenia referatów i posterów: 77 .

Kowalski A., 2017d. Fault geometry and evidence of depocentre migration within a transtensional intra-basinal high - a case study from the Łączna Anticline (Intrasudetic Synclinorium, SW Poland). Geological Quarterly 64(4): 779-794.

Kryza J., Niśkiewicz J., 1973. O występowaniu buł porfirowych z agatami w rejonie Nowego Kościoła (Dolny Śląsk). Rocznik Polskiego Towarzystwa Geologicznego 43(3): 391-404.

Łajczak A., Czajka B., Kaczka R.J, 2014. The new features of landslide relief discovered using LIDAR - case study from Babia Góra Massif, Western Carpathian Mountains. Quaestiones Geographicae 33(3): 77-88.

Maciejak K., Kowalski A., Maciejak M., 2017. Kopalnie złota na Wielisławce (Pogórze Kaczawskie). Hereditas Minariorum 4: 45-63.

Maciejak K., Maciejak K., 2006. Na tropach dawnego górnictwa Gór i Pogórza Kaczawskiego. Studio Edukacji i Aktywnego Wypoczynku Goldcentrum, Złotoryja.

Migoń P., Jancewicz K., Kasprzak M., 2014. Zasięg obszarów objętych osuwiskami w Górach Kamiennych (Sudety Środkowe) - porównanie map geologicznych i cyfrowego modelu wysokości z danych LiDAR. Przegląd Geologiczny 62(9): 463-471.

Migoń P., Jancewicz K., Różycka M., Duszyński F., Kasprzak M. 2016. Large-scale slope remodelling by landslides - Geomorphic diversity and geological controls, Kamienne Mts., Central Europe. Geomorphology 289: 134-151.

Migoń P., Różycka M., Michniewicz A., Kasprzak M., 2015. Identyfikacja form osuwiskowych na podstawie danych LiDAR - wybrane przykłady z Sudetów Środkowych i Zachodnich. Ogólnopolska Konferencja O!suwisko, Wieliczka, 19-22 maja 2015, Państwowy Instytut Geologiczny - Państwowy Instytut Badawczy, Warszawa: 107-108.

Mikulski S. Z., 2007. The late Variscan gold mineralization in the Kaczawa Mountains, Western Sudetes. Polish Geological Institute Special Papers 22: 1-162.

Milewicz J., 1985. Propozycja formalnego podziału stratygraficznego utworów wypełniających depresję północnosudecką. Przegląd Geologiczny 33(7): 385-389.

Milewicz J., Kozdrój W., 1994. Objaśnienia do Szczegółowej Mapy Geologicznej Sudetów. Arkusz Proboszczów. Państwowy Instytut Geologiczny, Warszawa.

Milewicz J., Kozdrój W., 1995. Szczegółowa Mapa Geologiczna Sudetów 1:25 000. Arkusz Proboszczów. Państwowy Instytut Geologiczny, Warszawa.

Oberc J., 1964. Główna sudecka dyslokacia diagonalna i jej znaczenie dla stanowiska synklinoriów waryscyjsko-laramijskich. Kwartalnik Geologiczny 8(3): 478-490.

Raport dostawy ISOK [Informatyczny System Osłony Kraju przed nadzwyczajnymi zagrożeniami], 2011. Część nr 3, Etap nr 03, 2011-09-12.

Różycka M., Michniewicz A., Migoń P., Kasprzak M., 2015. Identification and morphometric properties of landslides in the Bystrzyckie Mountains (Sudetes, SW Poland) based on data derived from airborne LiDAR. W: Jasiewicz J., Zwoliński Zb., Mitasova H., Hengl T. (red.), Geomorphometry for Geosciences: 247-250.

Sikora R., Wojciechowski T., Tomaszczyk M., Piotrowski A. 2017. Geological condition of landslides occurrence in the Bardzkie 
Mountains and adjacent areas (Sudetes, SW Poland). 4th World Landslide Forum, Lubljana, Slovenia.

Stefaniuk M., Ilcewicz-Stefaniuk D., 2012. Organy Wielisławskie. W: Słomka T. (red.), Katalog Obiektów Geoturystycznych w obrębie pomników i rezerwatów przyrody nieożywionej, AGH, Kraków: 88-91.

Synowiec G., 2003. Formy osuwiskowe w Górach Kamiennych. Przegląd Geologiczny 51(1): 59-65.

Traczyk A., 2011. Morfologia i geneza przełomowego odcinka doliny Kaczawy między Sędziszową a Nowym Kościołem na Pogórzu Kaczawskim. Przyroda Sudetów 14: 167-180.

Wężyk P. (red.) 2014. Podręcznik dla uczestników szkoleń z wykorzystania produktów LiDAR, Informatyczny System Osłony Kraju przed nadzwyczajnymi zagrożeniami. Główny Urząd Geodezji i Kartografii, Warszawa: 328.
Wojewoda J. 2016. O konieczności wykonania drugiej edycji Szczegółowej Mapy Geologicznej Sudetów w skali 1:25000 - przykłady rewizji budowy geologicznej z wykorzystaniem podkładu lidarowego numerycznego modelu powierzchni terenu. Przegląd Geologiczny 64(9): 597-603.

Wojewoda J., Białek D., Bucha M., Głuszyński A., Gotowała R., Krawczewski J., Schutty B., 2011. Geologia Parku Narodowego Gór Stołowych - wybrane zagadnienia. W: Geoekologiczne Warunki Środowiska Przyrodniczego Parku Narodowego Gór Stołowych: 53-96.

Zimmermann E., Kühn B., 1929. Geologische Karte von Preussen 1:25 000. Blatt Schönau.

Zöller A., 1936. Die Putzenzech am Willenberg. Ein altes Goldbergwerk bei Röversdorf unweit Schönaus in Niederschlesien. Zeitschrift für praktische Geologie 44: 109-112. 